\title{
Mezi historií a Evangeliem: Existence a život církve ve světle II. vatikánského koncilu
}

\section{PROKOP B R O Ž}

Ve dnech 4. a 5. dubna probèhla na Katolické teologické fakultě Univerzity Karlovy v Praze mezinárodní konference s názvem Mezi historii a Evangeliem: Existence a život církve ve svétle II. vatikánského koncilu. U příležitosti 50. výročí II. vatikánského koncilu se sešlo 17 přednášejících z tuzemska i ze zahraničí, aby nejen reflektovali historický vývoj, který se koncilem rozběhl, ale aby též hledali teologickou interpretaci mezitím již padesátileté historie univerzální církve.

První den byl zaměřen historicky a měl představit dobu koncilu i pokoncilní vývoj v evropském i národním kontextu tak, jak se s ním identifikovali postupně přicházející generace. Americký teolog, dominikán Thomas Benedikt Viviano uvedl celou konferenci přednáškou Recepce II. vatikánského koncilu ve svétle jeho prehistorie a rozlišování znamení doby. Následoval diskusní panel, který byl uveden třemi kratšími příspěvky: biskup František Radkovský zpracoval téma církevních hnutí a nových komunit v české církvi, docent Jaroslav Šebek přednesl zamyšlení nad vývojem českého katolicismu v pokoncilním období a Martin Vaňáč představil biskupskou synodu jako jeden z plodů II. vatikánského koncilu.

Odpolední blok zahájil prof. Jiří Hanuš přednáškou Problém kontinuity a diskontinuity církevního vývoje v moderné, na níž navázal doc. Stanislav Balík s příspěvkem Katolická církev $v$ Československu po II. vatikánském koncilu. Oba historici se tématu dlouhodobě věnují. Odpolední diskusní panel zahájil prof. Ctirad Václav Pospíšil zamyšlením nad několika významnými proslovy papežů Jana XXIII. a Pavla VI. Pokračoval doc. Aleš Opatrný vstupem, v němž reflektoval život církve 60. a 70. let s přihlédnutím k výzvám koncilu. Prof. Jan Sokol, jenž se nemohl dostavit, nicméně jeho příspěvek byl přečten, referoval o semináři v Jircháŕích. Prof. Peter Šturák, děkan Greckokatolické fakulty v Prešově, nastínil pokoncilní vývoj z pohledu řeckokatolické církve.

Druhý den konference měl za cíl představit dvě základní teologická témata, jež v současné církvi z koncilu vycházejí: evangelizace a pokoncilní vývoj chápaný jako recepce. Dopolední přednášku Význam II. vatikánského koncilu $v$ obnovené evangelizaci Evropy měl italský teolog Severino Dianich. V diskusním panelu, jenž následoval, vystoupil Jaroslav Brož, aby otevřel téma pokoncilní biblické exegese. Doc. Karel Sládek nastínil základní perspektivy spirituální teologie, jež se opírají o konstituce Dei Verbum a Sacrosanctum Concilium. Jaroslav Lorman předložil představu o základech mravní nauky církve ve svém příspěvku nazvaném Vznešenost povoláni vérících v Kristu. 
Odpolední blok začal italský teolog Marcello Paradiso přednáškou, v níž představil rozsáhlé dílo německého jezuity, působícího dnes v Paříži, Christopha Theobalda; $\mathrm{v}$ jeho stěžejním díle La réception du Concile Vatican II. je podán velmi propracovaný koncept recepce. Jde o proces recipování koncilu, který je nutné chápat jako život církve, jež vedena Duchem, v návaznosti na dvoutisíciletou tradici a věrná Písmu věnuje svoji pozornost současnosti, aby utvářela svoji podobu dnes a směřovala do budoucnosti. V posledním diskusním bloku vystoupil Prokop Brož s tématem vztahu mezi církví a společností, jenž se právě na koncil začal chápat nově. Michal Opatrný představil téma charity v souvislosti s dílem II. vatikánského koncilu. Panel uzavřel prof. Pavel Ambros s pastorálním tématem o obětním a koinonickém charakteru eucharistie. 